\title{
The effect of carprofen on fresh dairy cows health
}

\author{
Gabrielè Lošytė, \\ Ieva Navalinskaitè, \\ Žyginta Prokopavičiūtė, \\ Ernesta Pocevičienè, \\ Ramūnas Antanaitis \\ Large Animal Clinic, \\ Veterinary Academy, \\ Lithuanian University of Health Sciences, \\ Tilžès St. 18, 47181 Kaunas \\ Email: ramunas.antanaitis@lsmuni.lt
}

The aim of this study was to evaluate the impact of stress on the health of fresh-lactation cows and the effect of NSAIDs on the stress indicator cortisol, rumination time (RT) and somatic cell count (SCC).

The treatment group of cows (TG) $(n=15)$ were given a subcutaneous injection of Rimadyl Cattle ( $50 \mathrm{mg} / \mathrm{ml}$ of carprofen), $1.4 \mathrm{mg}$ per $1 \mathrm{~kg}$ BW dose, up to 1 hour after calving. At the same time, the control group of cows (CG) $(n=15)$ were given an injection of $0.9 \% \mathrm{NaCl}$. The whole study looked at the health of cows by recording cases that occurred during the period after calving. Blood cortisol examination was performed within 2,24 and $48 \mathrm{~h}$ after the use of the mentioned drugs. Rumination time was registered with the Lely T4C management program for analysis. Milk composition (SCC) was determined using the Lely T4C management program for analysis.

NSAIDs (carprofen $50 \mathrm{mg} / \mathrm{ml}$ ) statistically significantly reduced cortisol plasma concentrations within $48 \mathrm{~h}$ from the use of the drug and did not have an impact on SCC. The use of NSAID increased the average ruminating time from the third to the eleventh day after calving.

Keywords: cow, somatic cell count, cortisol, rumination time

\section{INTRODUCTION}

Cortisol is known to cause immunosuppression and, therefore, increase the risk of infection. High circulating cortisol concentrations were reported to be linked with reduced milk yields (Negrao, Marnet, 2003). Stress stimulates the release of adrenocorticotropic hormone from the pituitary gland which promotes the production of the steroid hormone cortisol from the cortex of the adrenal glands. This steroid hormone is more important in altering the body's metabolism (i.e. raising plasma glucose) under conditions of longer-term, ongoing (chronic), rather than acute stress (Berci, 2002). High levels of blood cortisol are a response to a physical stress (Garcia, 2011). Disbudding causes severe pain in calves and only the association of regional anaesthesia with carprofen assures good welfare for $24 \mathrm{~h}$ (Stilwell,
2008). Providing analgesia to a postpartum cow is not a common intervention following an unassisted calving but may be used following dystocia, retained placenta membranes, and is commonly used following a caesarean. Behavioural clinical and production measures may all be used to indicate pain (Broom, Fraser, 2007). Some of the trends in the behavioural clinical and production data suggest that analgesic use does have a positive effect on the welfare of post parturient cows and on the milk yield from primiparous animals (The pain management after parturition leads to earlier feed intake after calving and this may lead to a higher milk yield in first-lactation animals (Stilwell et al., 2014)). Inflammation and pain are more likely to appear and possibly be stronger among primary cows due to the narrower area of the pelvis slower calving and insufficient vulvovirus proliferation during calving 
(Mee, 2004). Nonsteroidal anti-inflammatory drugs (NSAIDs) are frequently used as adjunctive therapy to antibiotics. Carprofen treatment improved the general clinical condition by effective antipyrexia and restoration of reticulorumen motility but did not significantly inhibit eicosanoid production (Vangroenweghe et al., 2005). According to Paull et al. (2007) more research is needed to determine the effect of NSAID usage on the effectiveness of combination therapy. Postpartum analgesia is somewhere applicable but data is lacking to provide recommendations (Stilwell et al., 2014). NSAID administration in postpartum cows has the potential to be a viable way to improve productivity and potentially longevity in commercial dairies although further research is necessary to optimize recommendations for producers (Carpenter et al., 2016). Carprofen is an appropriate analgetic to reduce pain in cattle (Stilwell et al., 2014).

The aim of this study was to evaluate the impact of stress on the health of fresh-lactation cows and the effect of NSAIDs on the stress indicator cortisol, rumination time (RT) and somatic cell count (SCC).

\section{MATERIALS AND METHODS}

\section{Location, animals and experimental design}

The research was carried out on a dairy farm in the East Region of Europe at 5600 N, 2400 E. There were 600 lactating Lithuanian Black and White cows, each month 40-50 calving cows, and, according to the analogue principle (the age of breeding etc.), 30 cows from 1 to $12 \mathrm{~h}$ after calving. The cows selected for the study were clinically healthy (an average rectal temperature was $38.8^{\circ} \mathrm{C}$, rumen motility $5-6$ times per $3 \mathrm{~min}$, without clinical signs of mastitis, laminitis or metritis), examined according to a general plan for clinical examination.

The cows were divided into two groups. The treatment group of cows (TG) $(n=15)$ were given a subcutaneous injection of Rimadyl Cattle ${ }^{\circ}$ (50 mg/ml of carprofen), dose $1.4 \mathrm{mg}$ per $1 \mathrm{~kg}$ BW, up to 1 hour after calving. At the same time, the control group of cows (CG) $(n=15)$ were given an injection of $0.9 \% \mathrm{NaCl}$. The whole study looked at the health of cows by recording cases that occurred during the period after calving.

\section{Measurements}

Blood was taken in vacuum tubes (BD Vacutainer, England). Blood samples were analysed with a Tosh Corporation AIA-360 apparatus. A fluorescence enzyme-linked immunosorbent assay was made for measuring cortisol levels. To evaluate milk composition, milk samples were taken within $1-2 \mathrm{~h}$ and 30 days after calving. The research was carried out by the State Enterprise 'Milk Research'. To assess the effect of stress on the health of fresh-dairy cows from day 1 to 30 after calving, indicators of illness that usually occurs in the post-calving period (milk content, ruminating, etc.) have been recorded using the computer herd management program.

The cows were milked with Lely Astronaut ${ }^{\circledR}$ A3 milking robots with free traffic. To motivate the cows to visit the robot, $2 \mathrm{~kg} / \mathrm{d}$ of concentrates were fed to them by the milking robot. The rations were calculated according to physiological standards. Rumination time was registered with the Lely $\mathrm{T} 4 \mathrm{C}$ management program for analysis. Milk composition (SCC) was determined using the Lely T4C management program for analysis.

\section{Data analysis and statistics}

The data were analysed using the Statistical Package for the Social Sciences 20.0. The findings were provided as mean values and standard deviations. The Pearson correlation, X2 test and linear regression equations were evaluated to define the relationship between investigated traits; the t-test was used to define statistical differences between the two groups. The results were considered significant when $P \pm 0.05$.

\section{RESULTS AND DISCUSSION}

\section{The effect of NSAIDs on the cows health}

It was found that during 30 days after calving $30 \%$ of the cows in the control group had hypocalcemia, 25\% had endometritis and 10\% had metritis. In the group treated with NSAIDs $12 \%$ had hypocalcemia, 10\% had endometritis and 5\% had metritis (Fig. 1).

According to literature in the period after calving, the body encounters a negative energy balance (NEB) and/or disproportionate energy metabolism (hepatic lipidosis, ketosis, subacute, 


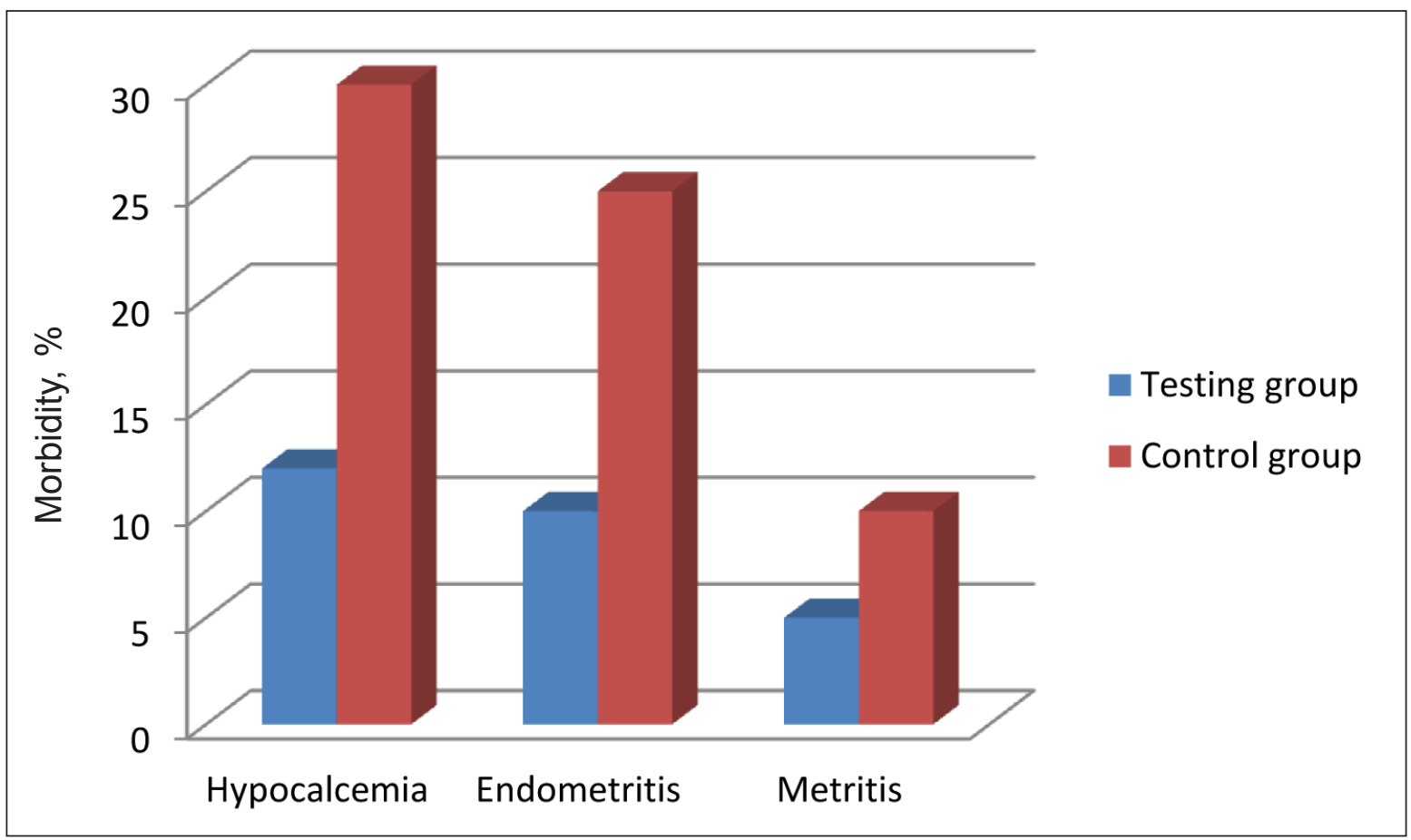

Fig. 1. Illness occurrence (\%) during the first month after calving

acute acidosis), immune system dysfunction (retained placenta, metritis, mastitis). For this reason, the energy balance is disturbed and the amount of taken dry matter (DM) is reduced. The combined effect of all these changes is reduced fertility and milk production, which leads to a decline in the farm profit. Risk factors such as pronounced NEB, inflammation and immune response disorders are highly related to an increase in the incidence of morbidity (Esposito et al., 2014). Using continuous video observation, Newby et al. (2013) demonstrated that meloxicam administered after calving in cows could alleviate some postcalving pain because treated cows increased the number of feeding visits and the total time spent. Postpartum pain control affects better feed intake which in turn can lead to a greater increase in milk production in the first lactation (Stilwell et al., 2014). Carprofen has been shown to improve the overall clinical status by acting antipyretically and improving rumen motility. The cow's body has to accumulate large reserves of fat and some proteins before calving, resulting in more frequent metabolic disorders such as hypocalcaemia, acidosis, ketosis, hepatic lipidosis and abomasum dislocation. Milk fever and ketosis affect uterine contractions, delay calving, increase the risk of retained placenta and en- dometritis. Nutrition risk factors that increase the chance of retained placenta are hypocalcaemia, a high body mass index during calving, vitamin E and selenium deficiency. Risk factors for endometritis include hypocalcaemia and retained placenta. In that way metabolic disorders cause gynecological illnesses, thus reducing reproductive efficiency (Roche, 2006).

\section{The effect of NSAIDs on the stress indicator (cortisol)}

During the study within 48 hours after administration of NSAIDs in TG, cortisol serum concentrations were statistically significantly reduced $(p>0.05)$. It was also found that in the control group between 24 and $48 \mathrm{~h}$ after administration of $\mathrm{NaCl}$ the cortisol concentration in the serum decreased, but the data were not statistically reliable (Table 1). According to the literature, when local anaesthesia and a non-steroidal anti-inflammatory drug (NSAID) are given before disbudding or dehorning, the cortisol responses to these procedures are virtually eliminated (Stafford, 2011). According to other authors' data, carprofen $(1.4 \mathrm{mg} / \mathrm{kg}$ of BW $)$ tended to reduce the integrated cortisol response, and it reduced cortisol secretion in banded animals between 6 and $12 \mathrm{~h}$ postcastration (Pang et al., 2006). 
Table 1. Change in cortisol serum concentrations (nmol/l) during the study. SE, standard deviation; T, testing group; C, control group

\begin{tabular}{cccccccc}
\hline Time, $\mathbf{h}$ & Group & Average, $\mathbf{n m o l} / \mathbf{l}$ & SE & Minimum & Maximum \\
\hline \multirow{2}{*}{2} & $\mathrm{~T}$ & 2.72 & 0.91 & 0.44 & 10.5 \\
\cline { 2 - 6 } & $\mathrm{C}$ & 1.6 & 0.27 & 0.21 & 3.24 \\
\hline \multirow{2}{*}{24} & $\mathrm{~T}$ & 1.3 & 0.26 & 0.29 & 2.95 \\
\cline { 2 - 6 } & $\mathrm{C}$ & 1.62 & 0.3 & 0.48 & 3.81 \\
\hline \multirow{2}{*}{48} & $\mathrm{~T}$ & 0.75 & 0.25 & 0.24 & 2.54 \\
\cline { 2 - 6 } & $\mathrm{C}$ & 0.96 & 0.19 & 0.27 & 1.96 \\
\hline
\end{tabular}

\section{Influence of NSAIDs on stress indicator (Somatic cell count (SCC))}

One hour later after calving in the test group SCC was lower (149. \pm 74.4 (thousand cells/ $\mathrm{ml})$ ) than in the control group $(356.2 \pm 1042.4$ (thousand cells/ml)). After 30 days postcalving, SCC in the test group was higher $(185.9 \pm 214.1$ (thousand cells/ml)) than in the control group $(147.57 \pm 364.1$ (thousand cells/ml)). In the testing group SCC was higher than in the control groups after 1 day and 30 days postcalving, but the physiological limits were not exceeded ( $\mathrm{Ta}-$ ble 2). Scientists found that treatment of cows with clinical mastitis with a combination of meloxicam and penethamate resulted in a lower SCC and a reduced risk of removal from the herd (culling) compared to the treatment with penethamate alone (McDougall, 2009).

\section{The effect of stress on the health of fresh} lactation dairy cows from 1 day to $\mathbf{3 0}$ days after calving by the computer herd management program (milk composition, rumination time)

One hour after calving, the concentration of urea in the cow milk of the testing groups was higher $(25 \pm 4.54(\mathrm{mmol} / \mathrm{l}))$ than in the control group of cows $(1535 \pm 4.68(\mathrm{mmol} / \mathrm{l}))$. After 30 days of calving in the testing group, the urea content of the cow's milk was lower $(18.28 \pm 3.3(\mathrm{mmol} / \mathrm{l}))$ than CG $(21.85 \pm 2.93(\mathrm{mmol} / \mathrm{l}))($ Table 3$)$. Sci- entists have found that milk protein increases in the first week after calving and depends on the protein/energy ratio of feed and the consumption of DM (Farney et al., 2011).

\section{Milk fat and protein ratio}

The milk fat/protein ratio of the test group was lower than that of the control group 1 hour after calving and 30 days after calving it was higher than that of the control group (Table 4). After 1 hour, the milk fat and protein ratio of the test group was 1.34, while that of the control group was 1.56. After 30 days, the difference was lower: in the test group the milk fat/protein ratio was 1.36 , in the control group it was 1.23 . The proportion of milk protein and fat in the experimental group varied less than in the control group. According to other studies, whole-lactation milk and protein yields were greater in NSAID-treated cows although 305-d fat production was not affected (Carpenter et al., 2016).

\section{Rumination time}

The study found that the average ruminating time of the experimental group from the third to the eleventh day after calving was statistically significantly $(p<0.05)$ higher than that of the control group of cows (Fig. 2). Chapinal et al. (2013) in the course of the study found out that control group cows ruminated less than

Table 2. SCC change during the study. SE, standard deviation; $\mathrm{T}$, testing group; $\mathrm{C}$, control group

\begin{tabular}{c|c|c|ccc}
\hline Time & Group & Average, thousand cells/ml & SE & Min. & Max. \\
\hline \multirow{2}{*}{ 1 hour after calving } & $\mathrm{T}$ & 149.42 & 74.39 & 60 & 264 \\
\cline { 2 - 7 } & $\mathrm{C}$ & 78.15 & 67.54 & 22 & 281 \\
\hline \multirow{2}{*}{ 30 days after calving } & $\mathrm{T}$ & 185.85 & 214.05 & 26 & 636 \\
\cline { 2 - 6 } & $\mathrm{C}$ & 50.92 & 44.17 & 12 & 165 \\
\hline
\end{tabular}


Table 3. Changes in milk urea during the study. SE, standard deviation; T, testing group; C, control group

\begin{tabular}{c|cccccc}
\hline Time & Group & Average, $\mathbf{m m o l} / \mathbf{l}$ & SE & Min. & Max. \\
\hline \multirow{2}{*}{1 hour after calving } & $\mathrm{T}$ & 25 & 4.54 & 19 & 30 \\
\cline { 2 - 7 } & $\mathrm{C}$ & 15.35 & 4.68 & 8 & 23 \\
\hline \multirow{2}{*}{30 days after calving } & $\mathrm{T}$ & 18.28 & 3.3 & 13 & 23 \\
\cline { 2 - 7 } & $\mathrm{C}$ & 21.85 & 2.93 & 15 & 27 \\
\hline
\end{tabular}

Table 4. Changes in milk fat and protein ratio during the study. SE, standard deviation; T, testing group; C, control group

\begin{tabular}{c|c|c|c|c|c}
\hline Time & Group & Average & SE & Min. & Max. \\
\hline \multirow{2}{*}{1 hour after calving } & $\mathrm{T}$ & 1.33 & 0.3 & 1.08 & 1.94 \\
\cline { 2 - 7 } & $\mathrm{C}$ & 1.56 & 0.22 & 1.24 & 1.9 \\
\hline \multirow{2}{*}{30 days after calving } & $\mathrm{T}$ & 1.36 & 0.21 & 1.14 & 1.8 \\
\cline { 2 - 6 } & $\mathrm{C}$ & 1.23 & 0.21 & 0.95 & 1.66 \\
\hline
\end{tabular}

flunixin treated cows within 5-8 h and $11-12 \mathrm{~h}$ after E. coli lipopolysaccharide (LPS) infusion although they ruminated more within $15-16 \mathrm{~h}$ after LPS infusion. Rumination time can be used to estimate within-cow variation in feeding behaviour and intake, but daily summaries of rumination behaviour are a poor indicator of DMI (Schirmann et al., 2013). According to past investigations, the RT is generally used for the early detection of metabolic diseases such as hypocalcemia, a displaced abomasum and ketosis (Moretti et al., 2017).

\section{CONCLUSIONS}

NSAIDs (carprofen $50 \mathrm{mg} / \mathrm{ml}$ ) have statistically significantly reduced cortisol plasma concentrations within $48 \mathrm{~h}$ from the use of the drug and did not have an impact on SCC. The use of NSAID increased the average ruminating time from the third to the eleventh day after calving.

\section{RECOMMENDATION}

In order to reduce cow stress after calving and improve its well-being, it is recommended to treat

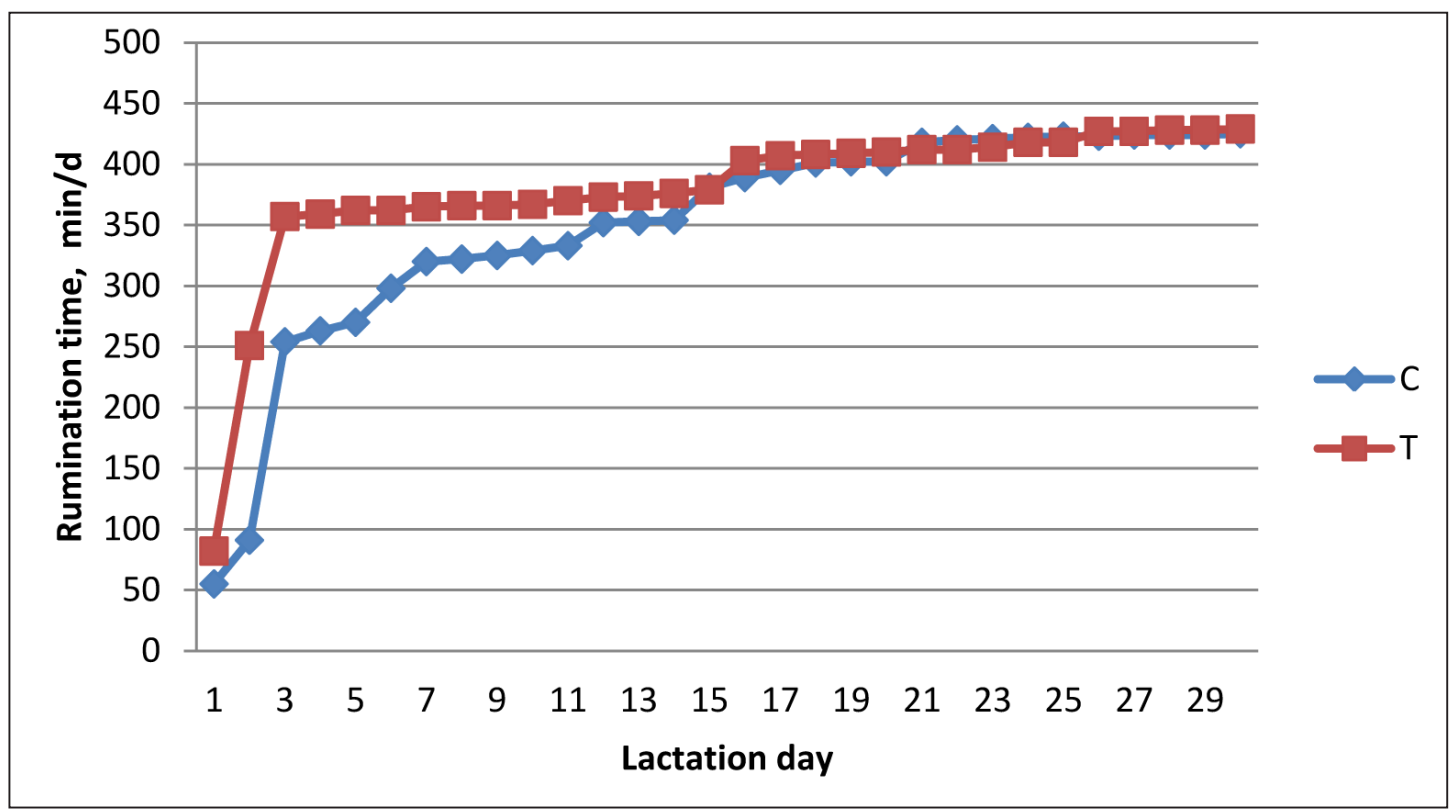

Fig. 2. Change in the duration of rumination during the study. C, control group; T, test group 
cows with NSAID (50 mg/ml carprofen), a dose of $1.4 \mathrm{mg} / \mathrm{kg} \mathrm{BM}$, in the first hour after calving.

Received 18 September 2018 Accepted 26 April 2019

\section{REFERENCES}

1. Berczi I. 2002. Neuroimmune Biology - An introduction. NeuroImmune Biology. Vol. 1. P. 3-45.

2. Broom D. M., Fraser A. F. 2007. Domestic Animal Behaviour and Welfare. 4th edn. Wallingford, UK; Cambridge, MA: CABI. P. 438.

3. Carpenter A. J., Ylioja C. M., Vargas C. F., Mamedova L. K., Mendonça L. G., Coetzee J. F., Hollis L. C., Gehring R., Bradford B. J. 2016. Hot topic: Early postpartum treatment of commercial dairy cows with nonsteroidal antiinflammatory drugs increases whole-lactation milk yield. Journal of Dairy Science. Vol. 99. P. 672-679.

4. Chapinal N., Fitzpatrick C. E., Leslie K. E., Wagner S. A. 2013. Short Communication: Automated assessment of the effect of flunixin meglumine on rumination in dairy cows with endotoxin-induced mastitis. Canadian Journal of Animal Science. Vol. 94(1). P. 21-25.

5. Deluyker H. A., van Oye S. N., Boucher J. F. 2005. Factors affecting cure and somatic cell count after pirlimycin treatment of subclinical mastitis in lactating cows. Journal of Dairy Science. Vol. 88(2). P. 604-614.

6. Esposito G., Irons P. C., Webb E. C., Chapwanya A. 2014. Interactions between negative energy balance, metabolic diseases, uterine health and immune response in transition dairy cows. Animal Reproduction Science. Vol. 144. P. 60-71.

7. Garcia D., Hahn M., Pino D., Soto E., Hernandez H. 2011. Blood cortisol levels in acute lame cows. Proceedings of the 16th International Symposium \& 8th Conference on Lameness in Ruminants.

8. McDougall S., Bryan M. A., Tiddy R. M. 2009. Effect of treatment with the nonsteroidal antiinflammatory meloxicam on milk production, somatic cell count, probability of re-treatment, and culling of dairy cows with mild clinical mastitis. Journal of Dairy Science. Vol. 92. P. 4421-4431.

9. Mee J. 2004. Managing the dairy cow at calving time. Veterinary Clinics of North America: Food Animal Practice. Vol. 20. P. 521-546.
10. Moretti R., Biffani S., Chessa S., Bozzi R. 2017. Heat stress effects on Holstein dairy cows' rumination. Animal. Vol. 11(12). P. 2320-2325.

11. Newby N. C., Pearl D. L., LeBlanc S. J., Leslie K. E., von Keyserlingk M. A., Duffield T. F. 2013. Effects of meloxicam on milk production, behavior, and feed intake in diary cows following assisted calving. Journal of Dairy Science. Vol. 96. P. 3682-3688.

12. Pang W. Y., Ezarley B., Sweeney T., Crowe M. A. 2006. Effect of carprofen administration during banding or burdizzo castration of bulls on plasma cortisol, in vitro interferon $-\gamma$ production, acutephase proteins, feed intake and growth. Journal of Dairy Science. Vol. 92. P. 2006-2527.

13. Paull D. R., Lee C., Colditz I. G., Atkinson S. J., Fischer A. D. 2007. The effect of a topical anaesthetic formulation, systemic flunixin and carprofen, singly or in combination, on cortisol and behavioural responses of Merino lambs to mulesing. Australian Veterinary Journal. Vol. 85. P. 98-106.

14. Roche J. F. 2006. The effect of nutritional management of the dairy cow on reproductive efficiency. Animal Reproduction Science. Vol. 96. P. 282-296.

15. Schirmann K., Chapinal N., Weary D. M., Vickers L., von Keyserlingk M. A. G. 2013. Short communication: Rumination and feeding behavior before and after calving in dairy cows. Journal of Dairy Science. Vol. 96. P. 7088-7092.

16. Stafford K. J., Mellor D. J. 2011. Addressing the pain associated with disbudding and dehorning in cattle. Applied Animal Behaviour Science. Vol. 135. P. 226-231.

17. Stilwell G., Limaa M. S., Carvalhob R. C., Broomc D. M. 2014. Effects of hot-iron disbudding, using regional anaesthesia with and without carprofen, on cortisol and behaviour of calves. Research in Veterinary Science. Vol. 92. P. 338-341.

18. Stilwell G. R., Campos de Carvalho M., Lima D. 2008. Broom Effect of caustic paste disbudding on cortisol and behaviour of dairy calves treated with regional anaesthetic. Proceedings of the 25th World Buiatrics Congress. Budapest, Hungary.

19. Vangroenweghe F., Duchateau L., Boutet P., Lekeux P., Rainard P., Paape M. J., Burvenich C. 2005. Effect of carprofen treatment following experimentally induced Escherichia coli mastitis in primiparous cows. Journal of Dairy Science. Vol. 88. P. 2361-76. 
Gabrielè Lošytė, Ieva Navalinskaitė, Žyginta Prokopavičiūtė, Ernesta Pocevičienė, Ramūnas Antanaitis

\section{KARPROFENO POVEIKIS ŠVIEŽIAPIENIU} KARVIŲ SVEIKATINGUMUI

Santrauka

Tyrimo tikslas buvo nustatyti streso poveikị šviežiapienių karvių sveikatingumui ir nesteroidinių vaistų nuo uždegimo itaką streso rodikliui kortizoliui, atrajojimo trukmei ir somatinių ląstelių skaičiui.

Tiriamosios grupès karvèms (TG $n=15)$ per pirmajją valandą po apsiveršiavimo po oda buvo suleista Rimadyl Cattle ${ }^{\circ}$ (50 mg/ml of carprofen), dozè 1,4 mg $1 \mathrm{~kg}$ kūno masès. Kontrolinès grupès karvèms (KG $n=15)$ po oda buvo suleista $0,9 \% \mathrm{NaCl}$. Tyrimas buvo atliekamas per pirmą mènesi po apsiveršiavimo. Kortizolio koncentracija kraujo serume buvo nustatoma praejjus 2, 24 ir 48 valandoms po minètų medikamentų panaudojimo. Atrajojimo trukmè (min./d) buvo registruojama Lely T4C bandos valdymo programa. Somatinių ląstelių skaičius buvo nustatomas Lely T4C programa.

Paaiškèjo, kad panaudojus nesteroidinius vaistus nuo uždegimo (carprofen $50 \mathrm{mg} / \mathrm{ml}$ ) statistiškai patikimai $(p<0,05)$ sumažėjo kortizolio koncentracija kraujo serume praëjus 48 val. po medikamentų panaudojimo, tačiau minètų medikamentų poveikio somatinių ląstelių skaičiui piene nenustatyta. Dèl nesteroidinių vaistų nuo uždegimo poveikio pailgèjo atrajojimo trukmé trečią-vienuoliktą parą po apsiveršiavimo.

Raktažodžiai: karvès, somatinių ląstelių skaičius, kortizolis, atrajojimo trukmé 